\title{
Physico-Chemical Characterizations and Fuel Potential Assessment of Chrysophyllum albidum Fruits from Benin
}

\author{
Cosme Sagbo Kouwanou ${ }^{1}$, Papin Sourou Montcho ${ }^{1}$, Cokou Pascal Agbangnan Dossa ${ }^{1}$, \\ Euloge Adjou ${ }^{2}$, Valentin Dieudonné Wotto ${ }^{3}$, Dominique Codjo Koko Sohounhloué ${ }^{1, *}$ \\ ${ }^{1}$ Unit of Research in Molecular Interactions, Polytechnic School of Abomey-Calavi, University of Abomey-Calavi, Cotonou, Benin \\ ${ }^{2}$ Unit of Research in Enzyme Engineering and Food, Polytechnic School of Abomey-Calavi, University of Abomey-Calavi, Cotonou, Benin \\ ${ }^{3}$ Laboratory of Physical Chemistry, Faculty of Sciences and Techniques, University of Abomey-Calavi, Cotonou, Benin
}

\author{
Email address: \\ csohoun@gmail.com (D. C. K. Sohounhloué) \\ ${ }^{*}$ Corresponding author
}

\section{To cite this article:}

Cosme Sagbo Kouwanou, Papin Sourou Montcho, Cokou Pascal Agbangnan Dossa, Euloge Adjou, Valentin Dieudonné Wotto, Dominique Codjo Koko Sohounhloué. Physico-Chemical Characterizations and Fuel Potential Assessment of Chrysophyllum albidum Fruits from Benin. American Journal of Physical Chemistry. Vol. 7, No. 3, 2018, pp. 50-54. doi: 10.11648/j.ajpc.20180703.12

Received: August 10, 2018; Accepted: September 25, 2018; Published: October 31, 2018

\begin{abstract}
This study aims to enhance agricultural resources and reduce post-harvest losses by assessing the physical and chemical characteristics of fruits and non-conventional vegetable oil extracted from Chrysophyllum albidum seeds in Benin. In this context, the fruits of Chrysophyllum albidum were collected in Tori (South Benin) and the morphological characteristics (mass, height and diameter at the equator) of the fruits, as well as the physico-chemical parameters (dry matter content, moisture content, ash content) were evaluated. The $\mathrm{pH}$, soluble dry matter (Brix) and glucose levels of the juice were also evaluated. The extraction of vegetable oil from the seeds was carried out in Soxhlet followed by the determination of biochemical parameters such as quality indices such as acid, peroxide, saponification and iodine indices. The physicochemical characterisation of this oil was also carried out through the determination of density, refractive index and net calorific value (PCI). Analysis of these results reveals that the fruits of Chrysophyllumalbidum have a mean equator mass, size and diameter of $43.79 \pm 3.15 \mathrm{~g}, 48.73 \pm 2.97 \mathrm{~mm}$ and $41.11 \pm 1.13 \mathrm{~mm}$ respectively. The levels of dry matter, moisture, and ash are respectively $51.60 \pm 0.47 \%, 48.40 \pm 0.47 \%$, and $24.7 \pm 0.96 \%$ with a $\mathrm{pH}$ of $3.67 \pm 0.12$ a Brix of $27.47 \pm 0.99$ and a glucose level of $27.57 \mathrm{mg} / \mathrm{mL}$. The oil extraction efficiency is $21.52 \pm 0.86 \%$ with a water and volatile matter content of $2.21 \pm 0.64 \%$. This vegetable oil has a dark red colour with an iodine value of $33.21 \pm 0.08 \mathrm{~g} \mathrm{I} / 100 \mathrm{~g}$-Oil, a saponification value of $188.40 \pm 4.18$ $\mathrm{mg} \mathrm{KOH} / \mathrm{g}$-Oil, an acid value of $3.60 \pm 0.23 \mathrm{mg} \mathrm{KOH} / \mathrm{g}$-Oil, a peroxide value of $10.46 \pm 0.12 \mathrm{meq} \mathrm{O} 2 / \mathrm{g}$-Oil and an ester value of $155.19 \pm 0.17 \mathrm{mg} \mathrm{KOH} / \mathrm{g}$-Oil. The density of vegetable oil at $30^{\circ} \mathrm{C}$ is 0.89 . The refractive index of vegetable oil at $30^{\circ} \mathrm{C}$ is 1.48 with a lower calorific value of $40287.92 \mathrm{~kJ} / \mathrm{kg}$. The results thus obtained indicate possible ways of using Chrysophyllum albidum fruits as biofuel.
\end{abstract}

Keywords: Chrysophyllum albidum, Fruit Morphology, Vegetable Oil, Caractérisation, Biofuel, Valorization, Benin

\section{Introduction}

Benin's rich and diverse flora consists of a mosaic of crops and fallow land with local forest islets and shrubby savannahs such as Parkya biglobosa, Anona squamosa, Cyperus esculentus, Lophira lanceolata and Chrysophyllum albidum. Some of these plant species have been the subject of in-depth studies at the Laboratory of Study and Research in Applied Chemistry [1-3].
This rich biodiversity, composed of fruit species, is poorly exploited. This poor performance can be linked to a deficit in terms of chemical knowledge, processes and equipment necessary for its recovery [4]. Chrysophyllum albidum belongs to the sapotaceae family and is a tropical evergreen tree reaching average heights of 25 to 37 metres with an average height of 1.5 to 8 metres [5]. It is a forest species widely distributed in West, Central and Eastern Africa and considered as a tree with a high socio-economic level [6]. 
These fleshy and juicy fruits are potential sources of soft drinks. Fruit is also suitable for the production of fruit jams and jellies [5]. Ecologically, the tree has an effective nutrient cycle and the high rate of leaf mineralization improves the superior quality of the soil. Their bark, leaves, fruit, roots and seeds could be used to cure a variety of diseases $[7,8]$. It is a domestic tree often found in villages, especially in southern Benin. It is used for many purposes and is marketed by the population. Thus the fruits of Chrysophyllum albidum, harvested during the month of November and April in the houses and in certain fields, are very early poured into the local markets to reach the secondary markets by the knowhow of several rural women and collectors of these markets. This trade generates for the actors involved in it an important monetary mass which helps them to solve certain problems which arise to them. Unfortunately, despite the wealth of this fruit, its production does not yet constitute a sector in Benin, for lack of organization of the sector. This state of affairs does not ensure the availability of raw materials. In addition, during the harvest period, a very large quantity of the fruit is destined for the dustbin. Only $10 \%$ to $20 \%$ of the fruit is consumed directly [9]. Thus, it proves necessary to valorize these fruits not exploited rich in sugar and lignocellulose. It is in this perspective that this study whose objective is to evaluate the biofuel potential of fruits and vegetable oil of Chrysophyllum albidum almonds for its valorization.

\section{Material and Methods}

\subsection{Collecte of Samples}

The fruits of Chrysophyllum albidum object of this study were collected in the zone of Tori in the south of Benin department of the Atlantic Municipality of Tori-Bossito more precisely in the village of wanho. Part of the fruit was used for the determination of morphological and chemical characteristics and the other for the determination of quality indices of the unconventional vegetable oil of Chrysophyllum albidum seeds.

\subsection{Determination of the Physical Characteristics of Fruits}

Physical characteristics such as mass, size and diameter at equator of Chrysophyllum albidum fruit were determined. The determination of the mass was made by weighing with a precision balance. The size and diameter at the equator were determined using a stainless steel stone [10].

\subsection{Determination of the Physicochemical Characteristics of Fruits}

\subsubsection{Dry Matter Rate and Moisture Rate}

The moisture content and the rate of dry matter were carried out according to the method devised by Jacquemin [11]. $20 \mathrm{~g}$ of sample were weighed and then placed in an oven at a temperature of $105^{\circ} \mathrm{C}$ until a constant dry mass after $24 \mathrm{H}$.

\subsubsection{Determination of Ash Content}

The ash content was done according to the method described by Jacquemin [11]. $1 \mathrm{~g}$ of dry sample is placed in a pre-weighed aluminum paper. The aluminum foil is put in a muffle oven at $550^{\circ} \mathrm{C}$ for 6 hours after cooling to room temperature and protected from moisture in a desiccators.

\subsubsection{Determination of the Brix Degree and the pH of the Juices}

The Brix of Chrysophyllum albidum fruit juice was determinate by direct measurement using a digital refractometer [12] and the $\mathrm{pH}$ was determined by direct measurement with a digital pH meter (HANNA HI 98129).

\subsubsection{Determination of Glucose Level}

The determination of the glucose level was made according to the phenol-sulfuric colorimetric method. To 1 $\mathrm{ml}$ of Chrysophyllum albidum juice is first added $1 \mathrm{ml}$ of a solution of phenol (5\%) then very slowly $5 \mathrm{ml}$ of concentrated sulfuric acid $\left(\mathrm{H}_{2} \mathrm{SO}_{4}\right)$. The mixture is stirred, and immediately placed in a water bath at $25-30{ }^{\circ} \mathrm{C}$ for 20 min. A stable yellow color develops. After cooling in water at room temperature, the absorbance is measured at $490 \mathrm{~nm}$ with the UV-Visible spectrophotometer. Two readings of concentrations are carried out per sample and the results are expressed in grams of total sugars per $100 \mathrm{~g}$ of mutton. The glucose concentration of the samples is determined from a calibration curve previously plotted with glucose [13].

\subsection{Pretreatment of Seeds and Extraction of Vegetable Oil}

The seeds of Chrysophyllum albidum were open air dried for seven (07) days at room temperature $\left(25^{\circ} \mathrm{C}\right)$ and mechanically crushed with a hammer. The manually separated almonds were in turn dried in the open air for ten (10) days and then baked at $30^{\circ} \mathrm{C}$. The almonds were then crushed. The extraction of the vegetable oil was carried out with Soxhlet according to standard NF V03-924.

\subsubsection{Determination of Physical Parameters of Vegetable Oil}

The water content and the density were respectively determined according to the standardized methods DIN EN ISO 12937 and NF T 60-214. The lower calorific power (PCI), using the formula of Batel et al, was calculated [14]. The refractive index (IR) was determined using the mathematical expression of Perkins et al [15]. The cetane number was calculated by Haidara's improved Klopfenstein formula [16].

\subsubsection{Determination of the Quality Indices of the Vegetable Oil}

The acid, peroxide and saponification indices of this vegetable oil are respectively determined according to the French standards T 60-204; T 60-220 and T 60-206. The iodine value was evaluated by the Winkler method [17]. 


\section{Result and Discussions}

\subsection{Physical Characteristics of Chrysophyllum Albidum Fruit}

Table 1 presents the results of the evaluation of the physical characteristics of Chrysophyllum albidum fruit collected in Tori (South Benin). The analysis of these results shows that the fruits of Chrysophyllum albidum have an average mass of $43.79 \pm 3.15 \mathrm{~g}$. This result is inferior to that reported by Lougbégnon et al [18] on samples of Chrysophyllum albidum collected in coastal areas, Pobè, Plateau and in the Ouémé Valley (South Benin). This difference observed at the mass level could be due to the characteristics of the Study Zones.

The results obtained at the level of determination of the average size (Table 1) of Chrysophyllum albidum fruits collected in Tori (South Benin) also indicate a significant difference compared to previous work. Indeed, the analysis of the results in Table 1 shows that the average fruit size of Chrysophyllum albidum is $4.87 \pm 2.97 \mathrm{~mm}$. This value is greater than that obtained for the same plant species harvested respectively at Pobè and Plateau [18]. However, she is lower than that obtained in the coastal zones and in the Ouémé valley (south Benin) [18]. These differences observed at the level of size may also be relating to soil characteristics, pluviometry, soil $\mathrm{pH}$, and even the various stresses on the tree. These results are also in agreement with those obtained during the determination of the equator diameter of the fruits of Chrysophyllum albidum (Table 1), which also indicate a significant difference between the values obtained and collected referenced in the literature [18]. These results therefore show that agroecological factors significantly influence the physical characteristics of Chrysophyllum albidum fruits.

\subsection{Physicochemical Characteristics of Chrysophyllum Albidum Fruit}

The results obtained during the evaluation of the physicochemical characteristics of the fruits of Chrysophyllum albidum (Table 1) show that the fruits of Chrysophyllum albidum collected in Tori (South Benin) have a dry matter content of $51.60 \pm 0,47 \%$. This proves that this fruit contains less water, therefore contains more lignocellulosic material which can be an advantage for its valorisation in second generation bioethanol. These results indicate that the fruit of Chrysophyllum albidum has a higher dry matter content than that reported by Abdessemed et al [19] on the fruits of Crataegus azarolus fruit.

The results obtained at the level of determination of the moisture content of Chrysophyllum albidum fruits collected in Tori (South Benin) indicate that these fruits have a moisture content of $48,40 \pm 0.47 \%$ lower than that reported by Abdessemed et al [19] on the fruits of Crataegus azarolus. According to Bretaude and Fauré [20], water is an important parameter in the dissolution of mineral salts, sugars, enzymes and other compounds contained in fruits. This fruit, according to its moisture content, can be classified as dry fruit because the percentages in water are of the order of 5 to $50 \%$ for the dried fruits and 80 to $90 \%$ for the fleshy fruits [21]. Chrysophyllum albidum therefore appears one of the least hydrated fresh fruits. These results are also in agreement with those obtained during the determination of the ash content of Chrysophyllum albidum fruits. This result is superior to that obtained with fruits of Crataegus azarolus [19]. As for the Brix degree, the results obtained show that the fruits of Chrysophyllum albidum collected in Tori (South Benin) have a Brix degree of $27.47 \pm 0.99 \%$.

This result therefore shows the possibility for valorization the waste from this fruit through its bioconversion into bioethanol by fermentation, in the face of significant post-harvest losses. The $\mathrm{pH}$ of $3.67 \pm 0.12$ obtained at level of the fruit juice (Table 1 ) is also a major advantage for a bioconversion of this juice into bioethanol by fermentation from yeasts, because the $\mathrm{pH}$ is a determining parameter and is one of the main obstacles that microbial flora must overcome to ensure its proliferation. Thus, a $\mathrm{pH}$ of the order of 3 to 6 is very favorable to the development of yeasts and molds [20]. Finally, the results of the evaluation of the glucose level of Chrysophyllum albidum fruits collected in Tori (South Benin) show that the glucose concentration of Chrysophyllum albidum juice is $27.57 \mathrm{mg} / \mathrm{ml}$; this also highlights the possibility of bioconversion of Chrysophyllum albidum fruits into biofuel.

Table 1. Morphological and Physicochemical Characteristics of Chrysophyllum albidum Fruit.

\begin{tabular}{ll}
\hline Parameters & values \\
\hline Mass $(\mathrm{g})$ & $43,79 \pm 3,15$ \\
Height $(\mathrm{mm})$ & $48 \pm 2,97$ \\
Diameterat the $(\mathrm{mm})$ & $41,11 \pm 1,13$ \\
Dry matter content $(\%)$ & $51,60 \pm 0,47$ \\
Rate humidity $(\%)$ & $48,40 \pm 0,47$ \\
Ash rate $(\%)$ & $24,7 \pm 0,96$ \\
$\mathrm{pH}$ & $3,67 \pm 0,12$ \\
Brix level & $27,47 \pm 0,99$ \\
glucose concentration $(\mathrm{mg} / \mathrm{mL})$ & 27,57 \\
\hline
\end{tabular}

\subsection{Qualities of Vegetable Oil Extracted from Chrysophyllum Albidum Almonds}

Table 2 presents the results of the assessment of the quality of the vegetable oil extracted from almonds of Chrysophyllum albidum. Analysis of this extraction table indicates that water and volatile matter content have a significant influences the vegetable oil yield. Thus, for a water content and volatile matter of the crushed Chrysophyllum albidum kernels $(3.44 \pm 0.17 \%)$, an extraction yield of $(21.52 \pm 0.86 \%)$ is obtained. This lipid content is close to that obtained for seeds of Eriospermum abyssinicum (28\%), Solanumnigrum and Dacryodesedulis (34\%) [22-24]. Thus this seed can be considered as a source of lipid material that can be valorized for multiple applications. Similarly, the vegetable oil of Chrysophyllum albidum is a dark red liquid with a density between 0.89 and 0.95 with a pleasant smell. The refractive index of this vegetable oil taken at $30^{\circ} \mathrm{C}$ is between 1.4615 and 1.4730. This value is well within the standard limit set by 
NAFDAC $[25,26]$. As regards the lower calorific power, its value is $40287.92 \pm 125.69 \mathrm{KJ} / \mathrm{Kg}$. This value is close to that of vegetable oil of Jatropha curcas $(41940 \mathrm{KJ} / \mathrm{Kg})$ and that obtained with diesel $(43669 \mathrm{KJ} / \mathrm{Kg})$ [27].

Cetane number assesses the ability of a fuel to ignite. This characteristic is particularly important for diesel fuel where the fuel must "self-ignite" under the effect of the compression of the air enclosed in the cylinder. The higher cetane number, more the ignition delay is short and the better the combustion quality. The cetane number of Chrysophyllum albidum vegetable oil is 49,57 $\pm 0,20$. This cetane number value is close to that of Petrodiésel recommended by ASTM D975 (40 to 55).

The chemical characteristics of the oil are presented in Table 2. The analysis in this table shows that the acid value of the vegetable oil of Chrysophyllum albidum is $3.60 \pm 0.23$ $\mathrm{mg} \mathrm{KOH} / \mathrm{g}$-Oil. This value obtained is in agreement with that found by Nkafamiya et al. This result shows the acid character of the oil analysed and suggests its probable use in the paint and varnish industry [28]. The saponification index value of the vegetable oil of Chrysophyllum albidum is $188.40 \pm 4.18 \mathrm{mg} / \mathrm{KOH} / \mathrm{g}$-oil. This value of the saponification index is lower than that obtained by Amoukou et al on sesame oil (189-190 mg KOH / g-oil) [29]. This result allows to consider the use of this oil in savonnerie.. In addition, the peroxide value of Chrysophyllum albidum vegetable oil is $10.46 \pm 0.12 \mathrm{meq} \mathrm{O}_{2} / \mathrm{g}$-Oil. This result shows that this vegetable oil is little degraded. The peroxide value obtained is higher than the standard established by NAFDAC and CODEX which say that the peroxide value should be less than $10 \mathrm{meq} / \mathrm{kg}$ [30]. The iodine value of this oil is $33.21 \pm$ $0.08 \mathrm{~g} \mathrm{I} / 100 \mathrm{~g}$-Oil. This iodine value is low and similar to that of palm and peanut vegetable oils [31]. For against, this value is much lower than those reported for Monodor amyristica vegetable oil (177.5 g I2/100 g-Oil) and linseed oil (170 to $190 \mathrm{~g} \mathrm{I} / 100 \mathrm{~g}$-Oil) [32]. This value of the iodine index also informs about the saturated nature of the vegetable oil of Chrysophyllum albidum.

Table 2. Physical parameters of Chrysophyllumalbidum vegetable oil.

\begin{tabular}{ll}
\hline Parameters & Values \\
\hline that water and volatile matter $(\%)$ & $2.21 \pm 0.64$ \\
extraction yield $(\%)$ & $21.52 \pm 0.86$ \\
Density à $30^{\circ} \mathrm{C}$ & 0.8926 \\
refractive index in $30^{\circ} \mathrm{C}$ & $1.4627 \pm 0.0183$ \\
net calorific value $(\mathrm{PCI})(\mathrm{kJ} / \mathrm{kg})$ & $40287.92 \pm 125.69$ \\
cetane number & $49.57 \pm 0.20$ \\
\hline
\end{tabular}

Table 3. Quality indices of Chrysophyllumalbidum vegetable oil.

\begin{tabular}{ll}
\hline Parameters & Values \\
\hline acid Index (mg KOH/g-Huile) & $3.60 \pm 0.23$ \\
peroxide Index (méq O 2 /g-Huile) & $10.46 \pm 0.12$ \\
saponification Index (mg KOH/g-Huile) & $188.40 \pm 4.18$ \\
iodine number $\left(\mathrm{g} \mathrm{I}_{2} / 100 \mathrm{~g}-\mathrm{Huile}\right)$ & $33.21 \pm 0.08$ \\
ester number (mg KOH/g-Huile) & $155.19 \pm 0.17$ \\
\hline
\end{tabular}

\section{Conclusion}

This study shows the physico-chemical characteristics of the ripe fruits of Chrysophyllum albidum as well as the quality indices of its non-conventional vegetable oil. Given the significant post-harvest loss and the results obtained, Chrysophyllum albidum fruits are rich in lignocellulosic, nutritional and glucose matter $(27.57 \mathrm{mg} / \mathrm{mL})$. In addition, in the face of the recurrent problem of fossil energy, this raw material represents a potential source of renewable energy production, such as bioethanol. In addition, the almonds contained in the seeds also offer good lipid potential. In addition, this vegetable oil could be used in soap-making given the value of its saponification index. The quality index values show that this oil would be suitable for use in cosmetics and even for biodiesel production.

\section{References}

[1] Djenontin, T. S. (2006). Study of oil seeds from Benin: chemical characterization, fractionation and biocidal activity. Doctoral thesis.

[2] Nonviho, G., Paris, C., Muniglia, L., Sessou, P., Agbangnan, D. C. P., Brosse, N., \& Sohounhloue, D. (2014). Chemical characterization of Lophira lanceolata and Carapaprocera seed oils: Analysis of fatty acids, sterols, tocopherols and tocotrienols. Research Journal of Chemical Sciences, 4 (9), $57-62$.

[3] Sidohounde, A., Nonviho, G., Djenontin, S. T., Agbangnan, P., Paris, C., \&Sohounhloue, D. C. (2015). Physico-Chemical Characterization of Vegetable Oil and Defatted Meal from Two Varieties of Cyperusesculentus from Benin. Chem J, 4, 17.

[4] Ambé, G. A. (2001). Les fruits sauvages comestibles des savanes guinéennes de Côte-d'Ivoire: état de la connaissance par une population locale, les Malinké. Biotechnologie, Agronomie, Société et Environnement, 5 (1), 43-58.

[5] Gbeyetin F. J. G., Tente B., et Lougbegnon T. (2011): Structure diamétrique et caractérisation de l'habitat des peuplements du Chrysophyllum albidumG. Don (Sapotaceae) sur le plateau d'Allada au Bénin.

[6] Bolanle-Ojo O. T. and Onyekwelu J. C. (2014) SocioEconomic Importance of Chrysophyllum Albidum G. Don. IN Rainforestand Derived Savanna Ecosystems of Ondo State, Nigeria European Journal of Agriculture and Forestry Research Vol. 2, No. 3, pp. 43-51.

[7] Isss, I. FAO. (1998): World reference base for soil resources, 84.

[8] Adewusi, H. A. (1997): The African Star Apple Chrysophyllum albidum Indigenous Knowledge from Ibadan, Southwestern Nigeria. In Proceedings of a National Workshop on the potentials of the African Star Apple, Ibadan, Nigeria (pp. 25-33).

[9] Kougnande C. (2017):Azongogwé ou Pomme étoile: Un fruit à fortes valeurs nutritives; Sciences et Santé.

[10] Gbohaïda, V., Mossi, I., Adjou, E. S., Agbangnan, P., Yehouenou, B. B., \&Sohounhloué, D. C. (2015): Morphological and Physicochemical Characterizations of Cashew Apples from Benin for their use as Raw Material in Bioethanol Production. Int. J. Pharm. Sci. Rev. Res, 35 (2), 7 11 . 
[11] Jacquemin, L. (2012). Production d'hémicelluloses de pailles et de sons de blé à une échelle pilote. Etude des performances techniques et évaluation environnementale d'un agro-procédé (Doctoral dissertation).

[12] AOAC. (2003): Association of Official Analytical Chemists. Methods of Analysis. Washington D. C. $18^{\text {th }}$.

[13] Kouwanou S. C., Agbangnan Dossa C. P., Adjou E. S., Tchobo F. P., Bonou C., Soumanou M. M., Sohounhloué K. C. D (2018): Physicochemical and Enzymatic Hydrolysis of Eichhornia crassipes for the Production of Second-Generation Bioethanol; American Journal of Chemistry, 8 (2) p 41-44.

[14] Batel, W., Graef, M., Mejer, G. J., Möller, R., \& Schoedder, F. (1980): Pflanzenölefür die Kraftstoff-und Energieversorgung. Grundlagen der landtechnik, 30 (2).

[15] Perkins G., Physical properties of soybeans, in Erickson (Ed.), Practical handbook of soybean processing and utilization, 3 (Champaign, IL: AOCS Press, 1995) 29-38.

[16] H. Haidara, L. Vonna, and J. Schultz. (1996):Kinetics and Thermodynamics of Surfactant Adsorption at Model Interfaces: Evidence of Structural Transitions in the Adsorbed Films; American Chemical Society, 12 (13), pp 3351-3355.

[17] Sidohounde, A., Dossa, C. P. A., Nonviho, G., Montcho, S. P., \&Sohounhloue, D. C. K. (2018). Biodiesel potentials of two phenotypes of Cyperusesculentus unconventional oils. Journal of Petroleum Technology and Alternative Fuels, 9 (1), 1-6.

[18] Lougbegnon O. T, Nassi K. M. Gbesso G. H. F. (2015): Ethnobotanique quantitative de l'usage de Chrysophyllum albidum G. Don par les populations locales au Bénin: J. Appl. Biosci. 95 p 9028 - 9038 .

[19] Abdessemed H. (2013): Etude de l'Activite Biologiquedes Extraitsdu Fruitde Crataegus azarolus L.. Thèse de doctorat.. P122.

[20] Bretaudeau J., et Fauré Y. (1992):Atlas d'arboriculture fruitière. Ed. Tec et Doc. Paris.. 289p.

[21] Doukani K., Tabak S. (2014): Profil Physicochimique du fruit "Lendj" (ArbutusunedoL.) Revue «Nature \&Technologie». BSciences Agronomiques et Biologiques, $n^{\circ} 12 /$ Janvier 2015, Pages 53 à66.

[22] Kapseu, C., Mbofung, C. M., \&Kayem, G. J. (1997): Acides gras et tri acylglycérols des huiles de Cyperusesculentus et Balanites aegyptiaca. Sciences des aliments, 17 (5), 531-537.
[23] Ali, M., Ali, Q., Anwer, S., Khalid, H., Ahmad, A., Ali, A. Husnain, T. (2015): Estimation of Correlation among various morphological traits of Coronopusdidymus, Euphorbia helioscopia, Cyperusdifformis and Aristidaadscensionis. New York Science Journal, 8 (4).

[24] Dahouenon-Ahoussi, E., Degnon, R. G., Adjou, E. S., \& Sohounhloue, D. C. (2012): Stabilisation de la bière produite à partir de matières amylacées locales (Sorghum bicolor et Musa acuminata) par adjonction de l'huile essentielle de Cymbopogoncitratus. Journal of Applied Biosciences, 51, 3596-3607.

[25] Musa, M., Sulaiman, A. U., Bello, I., Itumoh, J. E., Bello, K., Bello, A. M., \&Arzika, A. T. (2012): Physicochemical properties of some commercial groundnut oil products sold in Sokoto metropolis. Northwest Nigeria. J. Biol. Sci. Biocons., $4,38-45$.

[26] Siyanbola, T. O., James, O. O., Eromosele, C. O., Akinsiku, A. A., Nwinyi, O., Edobor-Osoh, A.,... \&Falomo, A. (2013): Physicochemical Analysis, Phytochemical Screening and Antimicrobial Activities of some Vegetable Oil from Ogun State, Nigeria. International Journal of CurrentResearch, 5 (4), 992-997.

[27] Dorin, B., \&Gitz, V. (2008): Écobilans de biocarburants: une revue des controverses. Natures Sciences Sociétés, 16 (4), 337-347.

[28] Oyedeji, A. O., \&Afolayan, A. J. (2006): Chemical composition and antibacterial activity of the essential oil isolated from South African Menthalongifolia (L.) L. subsp. capensis (Thunb.) Briq. Journal of Essential Oil Research, 18.

[29] Amoukou, I. A., Boureima, S., \&Lawali, S. (2013): Caractérisation agro-morphologique et etude comparative de deux methodes d'extraction d'huile d'accessions de sésame (Sesamumindicum L.). Agronomie Africaine, 25 (1), 71-82.

[30] Alimentarius, C., \& Codex Alimentarius Commission. (2005). FAO. Roma Italia.

[31] Koroma, S., Mosoti, V., Mutai, H., Coulibaly, A., \&Iafrate, M. (2008): Vers un marché commun africain pour les produits agricoles. Etude FAO: Politiques Concernant les Produits Agricoles de Base (FAO).

[32] Okolie, P. N., Uaboi-Egbenni, P. O., \&Ajekwene, A. E. (2012): Extraction and quality evaluation of sandbox tree seed (Huracrepitan) oil. World J. Agric. Sci, 8 (4), 359-365. 